\title{
PENGARUH SEDUHAN RIMPANG KUNYIT KUNING (Curcuma longa Linn.) TERHADAP PEMAHAMAN BACAAN
}

\author{
Nathaniel Nickander Pramuditha Pekasa ${ }^{1}$, Fen Tih ${ }^{2}$, Julia Windi Gunadi ${ }^{3}$ \\ ${ }^{1}$ Fakultas Kedokteran Universitas Kristen Maranatha, Bandung, Indonesia \\ ${ }^{2}$ Bagian Biokimia, Fakultas Kedokteran Universitas Kristen Maranatha, Bandung, Indonesia \\ ${ }^{3}$ Bagian Fisiologi, Fakultas Kedokteran Universitas Kristen Maranatha, Bandung, Indonesia
}

\begin{abstract}
Increasing globalization makes human need knowledge to compete globally. One way to increase knowledge is by reading. Reading comprehension is the process of interpreting a reading in order to gain a thorough knowledge of the passage. Therefore it is necessary to consume beverage to improve energy and cognitive function. In this study, researcher used yellow turmeric rhizome steeping as an enhancer of cognitive function. The objectives of this research was to determine the effect of consuming yellow turmeric rhizome steeping on cognitive function which is reading comprehension. This study was quasi-experimental, comparative using pretest and post-test design, conducted on 30 men aged between 18-22 years. Participants were asked to do reading comprehension test (pretest) then consume $200 \mathrm{cc}$ of water mixed with 10 grams of yellow turmeric rhizome powder. Participants took rest for 90 minutes and asked to do reading comprehension test (post-test). The measured data was the reading comprehension test score, in the form of a correct answer of 10 questions. Data were analyzed using Wilcoxon Signed Rank Test. The average score of correct answers increased very significantly, before consuming yellow turmeric steeping was 47,33 to 73,33 after consuming yellow turmeric rhizome steeping with $p<0,001$. Therefore yellow turmeric rhizome steeping increases reading comprehension. Keywords: cognitive function, curcumin, reading comprehension, yellow turmeric
\end{abstract}

Korespondensi: Nathaniel Nicjander Pramuditha Pekasa, Fakultas Kedokteran Universitas Kristen Maranatha. Jl. Prof. drg. Surya Sumantri, M.P.H. No. 65 Bandung, Jawa Barat, Indonesia - 40164. E-mail: nnickander@gmail.com 


\section{PENDAHULUAN}

Meningkatnya globalisasi mengakibatkan manusia memerlukan pengetahuan untuk dapat bersaing secara global. Salah satu cara untuk memperoleh pengetahuan adalah membaca. Membaca merupakan kemampuan pokok yang harus dimiliki manusia selain mendengarkan, berbicara, dan menulis. ${ }^{1}$ Menurut data dari Central Connecticut State University (2016), Indonesia berada pada urutan ke 60 dari 61 negara yang cakap membaca dan menulis. ${ }^{2}$ Hal ini membuktikan diperlukannya peningkatan kecakapan membaca pada warga Indonesia.

Pemahaman bacaan adalah proses mengartikan suatu bacaan dengan tujuan untuk mendapatkan pengetahuan secara menyeluruh dari bacaan, bukan sekadar arti dari satu kata atau kalimat. ${ }^{3}$ Proses pemahaman bacaan berkaitan dengan fungsi kognitif, antara lain: atensi, bahasa, dan memori. Pada penelitian ini, penilaian pemahaman bacaan menggunakan metode menjawab pertanyaan dengan pilihan ganda, karena memiliki tingkat kepercayaan yang tinggi dan kemudahan dalam dilaksanakannya penelitian. Manusia mencari cara untuk dapat meningkatkan fungsi kognitif. Cara yang sering digunakan adalah mengonsumsi kopi atau teh sebelum belajar. Pada penelitian ini, peneliti menggunakan kunyit sebagai peningkat fungsi kognitif.

Kunyit adalah rempah berwarna kuning yang digunakan pada masakan terutama pada daerah Asia maupun sebagai alternatif pengobatan. Kunyit (Curcuma longa) termasuk dalam famili jahe-jahean (Zingiberaceae). ${ }^{4}$ Kurkumin adalah fitokimia yang dapat ditemukan pada rimpang kunyit. ${ }^{5}$ Kurkumin memiliki banyak fungsi antara lain antioksidan, antitumor, antiartritis, antiamiloid, antiiskemik, antiinflamasi dan reduksi terhadap stres, depresi, dan kecemasan. ${ }^{6}$ Belum pernah dilakukan penelitian langsung pengaruh antara pemberian kunyit kuning dan pemahaman bacaan. Maka dari itu peneliti tertarik untuk melakukan penelitian pengaruh pemberian seduhan rimpang kunyit kuning terhadap pemahaman bacaan.

\section{METODE}

Penelitian ini bersifat eksperimental semu, komparatif dengan menggunakan rancangan pre-test dan post-test. Data yang diukur adalah skor tes pemahaman bacaan, berupa jawaban benar dari 10 pertanyaan. Analisis data menggunakan uji Wilcoxon Signed Rank Test.

Sepuluh gram bubuk rimpang kunyit kuning diseduh dalam $200 \mathrm{cc}$ air dengan suhu $70{ }^{\circ} \mathrm{C}$, lalu didiamkan dalam suhu ruang sampai dapat diminum. Subjek penelitian terdiri dari tiga puluh orang lakilaki dewasa muda usia 18-22 tahun, sehat secara fisik dan mental, dengan BMI dalam batas normal $(18,5$ - 22,9), serta tidak mengonsumsi obat yang merangsang dan menghambat susunan saraf pusat.

Subjek penelitian berada pada tempat tenang dan tertutup dan diberikan lembar pre-test. Subjek penelitian diminta untuk membaca dan mengisi pertanyaan yang berkaitan dengan paragraf bacaan dalam waktu sebelas menit. Subjek penelitian diberi minum seduhan rimpang kunyit kuning. Setelah itu subjek penelitian diberi waktu istirahat selama sembilan puluh menit. Subjek penelitian diberikan lembar tes post-test dan diminta untuk membaca dan mengisi pertanyaan yang berkaitan dengan paragraf bacaan dalam waktu sebelas menit, kemudian skor pre-test dan post-test dihitung dengan cara jumlah jawaban benar dikalikan dengan 10 .

\section{HASIL}

Telah dilakukan uji normalitas Shapiro-Wilk pada data yang diperoleh dari skor hasil pretest dan post-test. Didapatkan hasil yang signifikan $(\mathrm{p}<0,05)$ pada data pretest dan post- test, menunjukkan bahwa distribusi data tidak normal. Sehingga dilanjutkan dengan uji nonparametrik Wilcoxon Signed Rank Test.

Skor pre-test (sebelum mengonsumsi seduhan rimpang kunyit kuning) berkisar antara 20 sampai 70 dengan rerata $47,33 \quad(\mathrm{SD}=12,847)$ sedangkan nilai post-test (sesudah mengonsumsi seduhan rimpang kunyit kuning) berkisar antara 40 sampai 100 dengan rerata 73,33 $(\mathrm{SD}=12,130)$. Untuk menentukan apakah terdapat perbedaan yang bermakna antara nilai pretest dan post-test pemahaman bacaan dilakukan uji statistik nonparametrik Wilcoxon Signed Rank Test dengan nilai $p$ sebesar $<0,01$ yang berarti terdapat peningkatan skor pemahaman bacaan yang sangat bermakna sesudah konsumsi seduhan rimpang kunyit kuning. 
Tabel 1. Karakteristik Subjek Penelitian

\begin{tabular}{cc}
\hline Kriteria & Jumlah \\
\hline Usia (tahun) & \\
18 & 4 \\
19 & 14 \\
20 & 9 \\
21 & 3 \\
BMI & \\
$18-23$ & 30 \\
\end{tabular}

Tabel 2. Hasil Uji Parametrik T Berpasangan Untuk Semua Rangsang Cahaya, Suara, dan Taktil

\begin{tabular}{llllll}
\hline & N & Kisaran & Rerata & Sd & Wilcoxon Signed Rank Test \\
\hline Pretest & 30 & $20-70$ & 47,33 & 12,85 & $\mathrm{p}=0,000^{* *}$ \\
Post-test & 30 & $40-100$ & 73,33 & 12,13 & \\
\hline
\end{tabular}

\section{DISKUSI}

Kandungan bahan aktif dalam kunyit kuning yang dapat meningkatkan kemampuan kognitif adalah kurkuminoid, minyak atsiri, dan karbohidrat yang terdapat dalam pati.

Penggunaan 10 gram bubuk rimpang kunyit kuning berdasarkan penelitian oleh Katherine dan Andrew yang menggunakan $400 \mathrm{mg}$ kurkumin murni. ${ }^{7}$ Kunyit kuning mengandung 3-4\% kurkumin,${ }^{8}$ maka dari 10 gram bubuk rimpang kunyit kuning didapatkan 300-400 mg kurkumin.

Penelitian oleh Jiben Roy menunjukkan bahwa kurkumin mengalami degradasi sebanyak 47\% 1 jam setelah dicampur dengan air. ${ }^{9}$ Peneliti menggunakan air $70^{\circ}$ celcius supaya waktu dari sejak air dicampur dengan bubuk rimpang kunyit sampai dapat diminum tidak lebih dari 1 jam, sehingga kunyit belum mengalami degradasi.

Soal pemahaman bacaan diambil dari buku tes potensi akademik ${ }^{10}$ dengan tingkat kesulitan yang distandarisasi dengan soal dari American College Testing. ${ }^{11}$ Waktu istirahat 90 menit antara konsumsi seduhan rimpang kunyit kuning dengan pengerjaan post-test berdasarkan uji pendahuluan yang dilakukan pada 8 subjek penelitian.

Penelitian oleh Cournot, menunjukkan bahwa BMI yang tinggi berasosiasi dengan skor kognitif yang rendah. Skor kognitif dinilai dengan word-list learning dan Digit-Symbol Substitution Test. ${ }^{12}$ Penelitian oleh Damaris, menyimpulkan bahwa underweight berasosiasi dengan gangguan kognitif, dinilai dengan metode Short Portable Mental State Questionnaire (SPMSQ). ${ }^{13}$ Dalam penelitian Virgnia, perbedaan gender memiliki pengaruh terhadap kemampuan kognitif. ${ }^{14}$ Maka dari itu, kriteria inklusi pada penelitian ini adalah lakilaki dengan BMI dalam batas normal $(18,5-22,9)$.

Kurkuminoid (2-9\%), antara lain curcumin $(60 \%)$, desmethoxycurcumin, monodemethoxycurcumin, bisdemethoxycurcumin, dihydrocurcumin, dan cyclocurcumin. ${ }^{15}$ Kurkumin meningkatkan kemampuan kognitif dengan menginhibisi enzim monoamin oksidase (MAO) yang mengkatalisis oksidasi monoamin seperti norepinefrin, dopamin, dan serotonin. Kurkumin mampu menginhibisi MAO-A yang mengoksidasi serotonin dan norepinefrin dan MAO-B yang mengoksidasi dopamin. Peningkatan kadar norepinefrin, dopamin, dan serotonin di otak dapat meningkatkan fokus, rasa bahagia, kemampuan belajar, memori. ${ }^{16}$ Kurkumin juga memiliki komponen antiinflamasi dengan menginhibisi enzim siklooksigenase, nuclear factor kappa-light-chainenhancer of activated B cells (NF-kB), dan inducible nitric oxide synthases ( $i \mathrm{NOS}$ ) sehingga proses inflamasi dan degeneratif di otak menurun lebih lambat dan meningkatkan kemampuan otak dalam memproses informasi. ${ }^{17}$ Minyak atsiri $(1,5-5,5 \%)$ yang mengandung sesquiterpene lactone turmerone, zingiberene $\alpha$-dan $\gamma$-atlantone, bisabolene, guaiane, germacrene, 1,8-cineole, borneol, $\delta$ - sabinene, caprilic acid, dehydroturmerone, 1-phenyl-HO-Npentane, limonene, linalol, eugenol, curcumenol, curcumenone, curlone, dan phelandrene. ${ }^{15}$ Minyak atsiri mengandung antioksidan yang dapat mencegah deposisi plak dalam jaras saraf untuk menghindari penyakit neurodegeneratif seperti dementia dan penyakit Alzheimer, menghirup minyak atsiri efektif untuk meningkatkan memori, fokus, dan konsentrasi. $^{18}$ Glukosa hasil metabolisme karbohidrat yang didapat dari pati yang terkandung dalam kunyit merupakan sumber energi utama bagi susunan saraf pusat, sehingga meningkatkan fungsi kognisi. ${ }^{19}$

Tze-Pin $\mathrm{Ng}$ et al. ${ }^{20}$ melakukan penelitian terhadap 1.092 subjek berusia lebih dari sama dengan 60 tahun tentang pengaruh frekuensi konsumsi curry terhadap skor Mini Mental State Examination (MMSE). MMSE adalah instrumen yang digunakan secara luas untuk menghitung fungsi kognitif, termasuk memori, atensi, bahasa, 
dan kemampuan visuospasial. Perbandingan antara subjek yang tidak pernah atau kadang-kadang mengonsumsi curry, subjek yang mengonsumsi curry menunjukkan rata-rata skor MMSE yang lebih tinggi $(p=0,004)$. Perbandingan secara statistik

\section{SIMPULAN}

Mengonsumsi seduhan kunyit kuning meningkatkan pemahaman bacaan.

\section{PENDANAAN}

hibah manapun.

Penelitian ini tidak didanai oleh sumber

\section{KONFLIK KEPENTINGAN}

Tidak ada potensi konflik kepentingan.

\section{DAFTAR PUSTAKA}

1. Olviyanti I, Marbun R, Arifin Z. An Analysis on the Ability Comprehending a Reading Text by the Sixth Year Students. J Pendidikan dan Pembelajaran. 2015;1(4): 1-11.

2. Miller JW. McKenna MC. World Literacy How Countries Rank and Why it Matters. United States:Routledge. 2016;110-112.

3. Hall WS. Reading Comprehension. Tesol Quaterly. 1989;44(2):157-161.

4. Neena E, Eapen T. Turmeric: The Intriguing Yellow Spice with Medicinal Properties in. Explor J Sci Heal. 2009;5(2):114-115.

5. Rainey-Smith SR, Brown BM, Sohrabi HR, et al. Curcumin and Cognition: a Randomised, Placebo- Controlled, Double-Blind Study of Community-Dwelling Older Adults. British J Nutri, 2016;115(12):2106-2113.

6. Tiwari V, Chopra K. Attenuation of Oxidative Stress, Neuroinflammation, and Apoptosis by Curcumin Prevents Cognitive Deficits in Rats Postnatally Exposed to Ethanol. J of Psychopharmacol (Berl). 2012;224(4):519-535.

7. Cox KHM, Pipingas A, Scholey AB. Investigation of the effects of solid lipid curcumin on cognition and mood in a healthy older population. $\mathbf{J}$ of Psychopharmacol. 2014;(5):642-51.

8. Chattopadhyay I, Biswas K, Bandyopadhyay U, Banerjee RK. Turmeric and curcumin: Biological actions and medicinal applications. Curr Sci. 2004;87(1):44-53.

9. Roy J, Leake ME, Barsha AS, Sherpa TL, Adebowale A, Heda G, et al. Thin Layer Chromatographic Analysis of Stability of Curcumin and Curcumin in Turmeric after Refluxing in Water and Using Double Mobile Phase after Heating in Edible Oils. $J$ of the Mississippi Acad of Sci. 2015;60(4):319-326. signifikan antara konsumsi curry "kadang-kadang" dengan "tidak pernah atau jarang" dan untuk "sering dan sangat sering" dengan "tidak pernah atau jarang".
10. Amien M. Target Skor 755 TPA OTO BAPPENAS. 1th ed. Indonesia : Jawa Tengah. 2012;42-158.

11. Lindquist EV. 2000. ACT Test Reading Placement Test Sample Question. ACT Compass.

12. Cournot M, Marquie JC, Ansiau D, Martinaud C, Fonds H, Ferrie'res J, Ruidavets JB. Relation Between Body Mass Index and Cognitive Function in Healthy Middle-Aged Men and Women. American Academy of Neurology. 2006;67(7):1208-14.

13. Damaris FEC, Jose AN, Lizzette GDR. 2016. Association Between Body Mass Index with Cognitive or Physical Functioning, and Depression in Mexican Elderly: A CrossSectional Study. Open Access J.

14. Virginia AM, Sumiko S, Naoko S, Shinobu M. 1990. Sex Differences in Cognitive Abilities :

A Crosscultural Perspective. Neuropsychol, 1990;28(10):1063-1077.

15. Ammon HP, Wahl MA. Pharmacology of Curcuma longa. Planta Med. 1991;57(1):1-7.

16. Kulkarni S, Dhir A, Akula K. Potentials of Curcumin as an Antidepressant. Sci World J, 2009;9:1233-1241.

17. Acheson A, Conover JC, Fandl JP, DeChiara TM, Russel M, Thadani A, et al. A BDNF Autocrine Loop in Adult Sensory Neurons Prevents Cell Death. NATURE. 1995;374(6521):450-3.

18. Verma S, Kumar V. Pharmacological Profile of Turmeric Oil : A Review. Lekovite Sirovine, 2015;35(2015) :3-21.

19. Das UN. 2001. Cognitive Performance and Glucose. American Journal Clinical Nutrition, 74:409-12.

20. Ng TP, Chiam PC, Lee T, Chua HC, Lim L, 
